\title{
A Criticism of Beutner's Theory of the Electromotive Force of Diphasic Liquid Systems and their Relation to Bio-electrical Phenomena.
}

\author{
BY
}

\begin{abstract}
DOROTHY HAYNES.
(From the Department of Plant Physiology and Pathology, Imperial College of Science and Technology, London.)
\end{abstract}

HE development of the theory of concentration cells and its extension
to two-phase systems has placed the study of bioelectrical phenomena upon an entirely new footing, and there are few physiologists who still doubt that it is within the scope of physical chemistry to furnish a complete explanation of such phenomena without the intervention of any specialized hypothesis. Nevertheless, much remains obscure, owing to the complexity of physical structure and chemical composition which is characteristic of the living organism, and none of the various theories put forward affords a complete explanation of the facts. It must be remembered that the generalizations of physical chemistry have been developed almost entirely from the study of very simple chemical compounds, and that in applying them to mixtures of complex organic substances there is some danger that insufficient attention may be paid to the essential differences between such mixtures and those of simple inorganic salts. It is by the careful study of these more complex systems that we may hope to attain to further comprehension of the electrical behaviour of living tissue.

Physiologists must therefore welcome so comprehensive a series of experiments as those described by Beutner in his recent work, ${ }^{1}$ although they may be unable to follow him in all his theoretical conclusions. The experiments in question were carried out on two-phase systems consisting of water and 'oil', i.e. a liquid immiscible with water. It is in the properties of such systems that Beutner seeks a clue to those of living tissues, and it is as a result of their investigation that he reaches the conclusion that it is the salt content rather than the acidity of the cell which determines its electrical behaviour. Such a view, if substantiated, is of fundamental impor-

1 R. Beutner : Die Entstehung elektrischer Ströme in lebenden Geweben. I920.

[Annals of Botany, Vol. XXXVII. No. CXLV. January, 1923.] 
tance for physiology, and no further justification will be needed for a careful review of the evidence upon which it is based.

The systems investigated by Beutner are of two general types, represented by the following schemes:

System I.

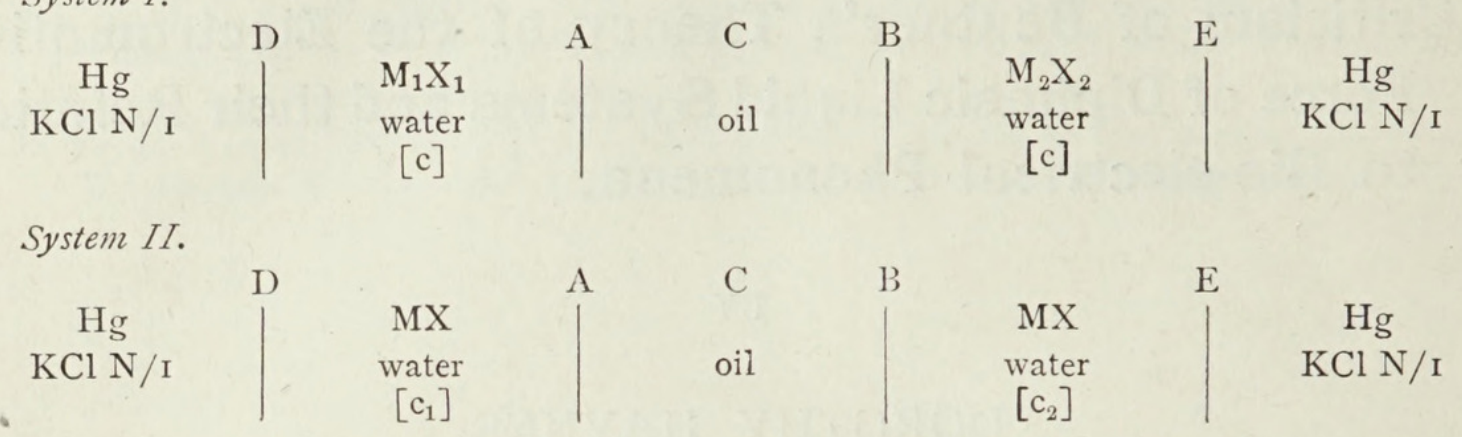

In these systems the potassium chloride in contact with the electrodes is frequently replaced by sodium chloride; MX represents a salt of which M is the cation and $\mathrm{X}$ the anion, and $\mathrm{c}, \mathrm{c}_{1}, \mathrm{c}_{2}$ in square brackets represent concentrations. It will be seen that System I consists of different salts of the same concentration in contact with 'oil'; System II of the same salt at different concentrations. In experimenting with systems of the type of System I, Beutner's general practice was to use salts having a common cation or a common anion. In this case $\mathrm{M}_{1} \mathrm{X}_{1}, \mathrm{M}_{2} \mathrm{X}_{2}$ will be replaced by $\mathrm{M}_{1} \mathrm{X}, \mathrm{M}_{2} \mathrm{X}$, or $\mathrm{MX}_{1}, \mathrm{MX}_{2}$. The 'oil' is a liquid which may be of very various chemical composition, ranging from acidic substances such as salicyclic aldehyde or benzaldehyde to definitely basic substances such as o.-toluidine.

In both systems potential differences may arise at the boundaries $A, B$, and $\mathrm{C}$. Those at $\mathrm{D}$ and $\mathrm{E}$ Beutner considers to be obliterated by the more concentrated salt solutions in contact with the electrodes.

Beutner follows Haber's method in deriving the theory of such systems from a consideration of the following :

metal $\quad \begin{gathered}\text { A } \\ \text { of salt }\end{gathered}\left|\begin{array}{l}\text { solution in oil of the same salt in } \\ \text { equilibrium with the aqueous } \\ \text { solution. }\end{array}\right|$, metal

The e.m.f. of this system is zero, since work cannot be done by transference of salt across the boundary $C$; hence the potential at $C$ is equal and opposite to the sum of the potentials at A and B. If, therefore, the hypothesis of solution pressure is extended to oils, the boundary potential can be expressed as :

$$
E_{c}=R T \log \frac{\mathrm{C} \text { water }}{\mathrm{C} \text { 'oil' }} \times \text { const . . . . }
$$

$\mathrm{C}$ water, C 'oil', representing the concentrations of the cation in the two liquids. 
In both the above systems two such interphasic potentials exist at $A$ and $B$, the difference of which is equal to

$$
R T \log \frac{\mathrm{C}_{1} \text { 'oil', }}{\mathrm{C}_{2} \text { 'oil }} \text {. }
$$

since the other factors cancel out; and in Beutner's opinion this expression represents the total e.m.f., which is therefore determined by the relative concentrations of the common ion $\mathrm{M}$ ( or $\mathrm{X}$ ) in the layers of oil adjacent to the aqueous solutions. There are, however, considerable difficulties in accepting the conclusion that the total e.m.f. can be expressed by a logarithmic formula of this type.

The derivation of expression (I) is not entirely satisfactory, since little is known of the 'solution pressure' of metals in liquids other than water. The same result can, however, be obtained by the use of Nernst's partition formula : ${ }^{1}$

$$
E=\frac{R T}{m_{1}} \log \frac{k^{+} y^{+}}{c^{+}} \text {(for positive ions) }=\frac{-R T}{m_{2}} \log \frac{k^{-} y^{-}}{c^{-}} \text {(for negative ions) }
$$

where $m=$ valency, $k$ partition coefficient between phases, $c$ and $y$ the concentration of the ions in the two phases.

More serious difficulties arise in its practical application. It should be remarked that the 'oil' in Beutner's experiment was not saturated with salt and was in equilibrium only at the surface layer. In most cases so little salt penetrated the oil that the salt produced no permanent effect upon its properties, and if a series of salts, of which the first and last members were the same, were brought into contact with the 'oil' the difference of potential at the beginning of the experiment was found to be identical with that at the end. The conductivity of the 'oil' must therefore have been mainly due to other ions, and since most of these 'oils' were acid it may be assumed that hydrogen ions played the principal part. Beutner's argument rests on the assumption that this hydrogen ion concentration is unaffected or is equally affected by the various salt solutions in contact with the 'oil'; which, however, can hardly be the case. Haber and Klemensiewicz ${ }^{2}$ draw attention to this point in connexion with Riesenfeld's experiments on phenol, and it seems probable that the discrepancy between theory and experimental results which the latter observes may be referred to this cause. In this case the discrepancy is of no great magnitude, but where free acid is present, as in many of Beutner's experiments, the effect becomes of far greater importance. To take the following example, Beutner draws an analogy between the 'oil' system:

1 See Riesenfeld: Ann. d. Physiol., viii. 6I6 (1902).

${ }^{2}$ Zeitsch. f. physik. Chem., lxvii. $3^{8} 5$ (I909). 


$+\mathrm{Na}$ in water $\left.\right|_{(\mathrm{Na} \text { oleate) }} ^{\mathrm{A}} \mathrm{Na}$ conc. $-\mathrm{Na}$ ' dil. $\left.\right|_{(\mathrm{NaCl})} ^{\mathrm{B}} \mathrm{Na}$ in water -

and the Nernst system:

$$
+\mathrm{Ag} \text { metal } \mid \mathrm{Ag}^{\circ} \text { conc. }-\mathrm{Ag}^{1} \text { dil. } \mid \mathrm{Ag} \text { metal - }
$$

and regards the former as a system reversible in respect to sodium ions, while he limits the effect of free acid in the 'oil' phase to that which it produces by increasing the solubility of the sodium salt. This is to ignore the fact that unless the ions of an electrolyte are completely insoluble in one of the two phases-an impossible assumption here-the distribution of these ions must affect the potential at the boundary, and this more especially where organic acids are concerned, since the partition coefficient between organic liquid and water is likely to be far higher for organic anions than for hydrogen ions.

In Beutner's systems the matter is further complicated by the nature of the salts in contact with the acid oil. Not only must the distribution of these salt ions be taken into account, but also the possibility of reaction.

We may consider the case of an 'oil' very frequently used by Beutner-a solution of salicylic acid in salicylic aldehyde. As salicylic acid is not insoluble in water as he supposes, it will react with the salts with which it is in contact, and double decomposition will take place at both boundaries. At A salicylic acid, oleic acid, sodium salicylate, and sodium oleate will be present; at B salicylic acid, hydrochloric acid, sodium salicylate, and sodium chloride. At A, therefore, there will be a decrease of hydrogen ion concentration; at $\mathrm{B}$ an increase. The effect of free hydrochloric acid is entirely ignored by Beutner, and his reasons for neglecting so potent a factor are discussed in the sequel. Here it will merely be pointed out that a solution of salicyclic acid will increase in acidity by admixture with sodium chloride, since salicylate ions will be removed as undissociated sodium salicylate and the concentration of hydrogen ions will consequently increase. When considerable quantities of undissociated salt are present this effect becomes important, and this has been shown by the writer ${ }^{1}$ to be the case in buffer solutions. An 'oil' in which undissociated salt is soluble will evidently produce a very similar effect, and in the system under discussion there will therefore be a difference of concentration of acid on the two sides; work will be done by the transference of hydrogen ions from a region of greater to one of less concentration, and on this account a difference of potential will arise.

Before going farther into this matter consideration must be given to the effect of diffusion potential. Beutner discusses this in connexion with the work of Haber and Klemensiewicz ${ }^{2}$ and of Cremer $^{3}$ on diphasic

\footnotetext{
1 Biochem. Journ. xv. 440 (1921). $\quad{ }^{2}$ loc. cit.

${ }^{3}$ Zeitsch. f. Biologie, xlvii. I (I906).
} 
systems. By a curious misinterpretation he regards their theories as mutually exclusive, and attempts to decide between them; whereas both recognize the possibility of potential differences arising at all three boundaries, and both attempt, by an appropriate adjustment of the conditions of experiment, to eliminate certain of these-Haber the diffusion potential at $\mathrm{C}$ by the interpolation of a phase of constant composition: Cremer the interphase potentials at $\mathrm{A}$ and $\mathrm{B}$ by similarity of composition in the two aqueous solutions. How far these devices are successful is of course a matter for criticism, and Beutner justly points out that the results of measurements of potential in Cremer's nitrobenzol-picric acid system do not bear out his theory, as is recognized by Cremer himself. ${ }^{1}$

Beutner denies the existence of a diffusion potential in the oil systems with which he deals on the ground that the addition of such a substance as salicyclic acid to the oil phase increases the e.m.f., whereas on the hypothesis of a diffusion potential the presence of excess of electrolyte on both sides should tend to obliterate it. In the light of the considerations discussed above, it will be seen that this argument has little force, and on theoretical grounds Beutner's general proposition, that no diffusion potential exists between solutions of different concentrations, is entirely inadmissible.

The total e.m.f. of 'oil' systems such as the above must therefore be the algebraic sum of the following :

1. The interphase potentials at $A$ and $B$. These will be determined by the relative concentrations of electrolytes in the layers adjacent to each boundary, and in certain cases their sum may be expressed by the formula $R T \log \frac{\mathrm{C}_{1}}{\mathrm{C}_{2}}$, where $\mathrm{C}_{1}, \mathrm{C}_{2}$ represent the concentration in 'oil' of salts present in equivalent concentration in the two aqueous solutions.

2. The diffusion potential due to difference of concentration and to difference in the nature of the ions on each side. Where the same electrolyte is present in different concentrations this potential can be calculated by

1 Cremer found the system
$\mathrm{M} / \delta \mathrm{NaCl}$
A
sat. with nitrobenzene
and picric acid
sat. with $\mathrm{NaCl}$ and
picric acid
Nitrobenzene
C
Nitrobenzene
sat. with $\mathrm{NaCl}$
B
$\mathrm{M} / \delta \mathrm{NaCl}$
sat with nitrobenzene
to be positive on the acid side. He regards the interphase potentials at $\mathrm{A}$ and $\mathrm{B}$ as equal and opposite, and ascribes the effect to diffusion potential at $\mathrm{C}$ in spite of the difficulty of maintaining this explanation. Beutner ascribes it to a difference of interphase potential at A and B arising from the greater solubility of sodium chloride in nitrobenzene containing acid, and quotes conductivity measurements to show that the solubility of sodium chloride in nitrobenzene is increased by the presence of picric acid. This argument is entirely inconclusive, for hydrochloric acid must be formed by the reaction of sodium chloride and picric acid, and a great part of the increased con- ductivity must be due to this cause. In the opinion of the writer, the effect is in all probability due to the fact that while picric acid is only slightly soluble in water, hydrogen ions are highly soluble. On this account an excess of hydrogen ions may easily be present in the aqueous phase even when the nitrobenzene phase contains only a very small quantity of dissociated acid. 
the well-known formula $R T \frac{u-v}{u+v} \log \frac{\mathrm{C}_{1}}{\mathrm{C}_{2}}$, where $u$ and $v$ are the velocities of cation and anion in the 'oil' phase.

In certain cases one or other of these potentials may become negligible. For example, in the system

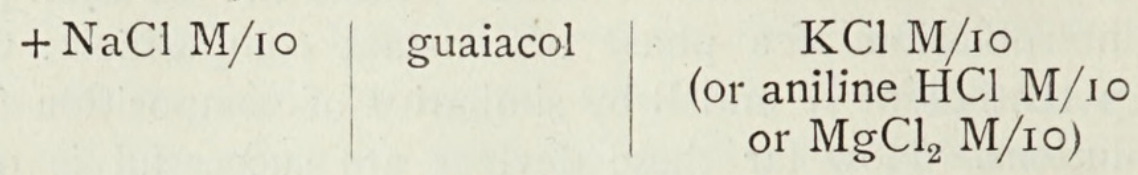

the measured e.m.f. agrees very closely with the logarithmic formula. In this case chemical reaction with guaiacol is probably negligible and diffusion potential very small, as would be the case if the various ions move with no great difference of velocity in the 'oil' phase. If so, Beutner's very precarious method of estimating the ratio of concentrations by changes of conductivity would also give valid results. In other cases diffusion potential must be very important. This is most probable where such a salt as sodium oleate is in question, and will account for the divergencies from the logarithmic formula observed by Beutner even where free acid is absent.

There is one group of experiments-expressed above by the scheme of System II-in which interphasic potentials play a part in somewhat different circumstances from those described above. Beutner has found that the production of an e.m.f. by difference of concentration is very largely dependent upon the presence of free acid and is greater with strong acids than with weak, but because the effect can be obtained with acids such as oleic acid, which are only slightly dissociated in water, he maintains that this effect is no 'measure' of the acidity. He looks upon it as due to 'non-proportional ionic distribution', i. e. to double decomposition. To make Beutner's outlook upon this matter clear, a statement will be quoted relating to the effect of potassium chloride on salicyclic aldehyde containing salicylic acid :

'Soviel ist aber sicher, dass $\mathrm{KCl}$ nicht nur als solches in dem säurehaltigen Aldehyd zugegen ist, sondern dass die freie Base sich mit der überschüssigen Säure vereinigt. Wie sollte sonst auch die Beobachtung zu erklären sein, dass pikrinsäurehaltiges Nitrobenzol mehr Salz bei Schütteln aufnimmt als säurefreies Nitrobenzol? Auch in diesem Falle muss eine solche Umsetzung mitspielen. Das durch Umsetzung gebildete Kalisalz unterliegt einer elektrolytischen Dissoziation; es entstehen also in dem säurehaltigen Aldehyd Kaliumionen, die nicht vom $\mathrm{KCl}$ herstammen. Um die Nichtproportionalität der Ionenverteilung zu erklären, ist ferner anzunehmen, dass die Konzentration des umgesetzten Kaliumsalzes im Aldehyd der wässrigen $\mathrm{KCl}-\mathrm{Konzentration}$ nicht proportional ist. Wie dies möglich ist, kann allerdings theoretisch noch nicht begründet werden.' ${ }^{1}$ 
It has been shown above that a simple explanation of the reaction exists, and that it is a necessary consequence of the establishment of equilibrium between dissociated and undissociated salt. How the writer of the above paragraph can have failed to realize that such a reaction connotes a change of hydrogen ion concentration is very hard to understand. $\mathrm{He}$ appears to have been led, by his experiments on the neutralization of acids by alkalies, to the conclusion that in solution in 'oils' all acids behave as weak acids, and that in consequence their dissociation is negligible compared with that of salts. Beutner's strongest acid however appears to have been salicylic acid, which, though highly dissociated in water, obeys the dilution law. Not only is it impossible for a chemist to regard the ionization of salicylic acid as throwing light upon that of hydrochloric acid, but very rigorous proof will be needed before chemists will be prepared to accept the proposition that the presence of varying quantities of any acid is without effect upon potential in such a system as that under discussion. In the case under consideration hydrochloric acid would diffuse at the boundary and would be present also in aqueous solution, and we have therefore the system exhaustively studied by Haber and Klemensiewicz in which solutions of different hydrogen ion concentration are separated by a phase in which the concentration of the ions is constant, the constancy in the present instance being due to the presence of a large excess of very slightly dissociated acid. There can be no reasonable doubt that the e.m.f. of systems of the type of System II is due to the same cause as that of the system studied by these two workers. Loeb ${ }^{1}$ calls attention to the fact that the differences of potential which Beutner would attribute to the presence of lipoid substances can also be obtained with proteins, and he suggests that the difference of potential may be due to the establishment of the Donnan equilibrium. This explanation, however, would hardly seem to meet the case, since the Donnan equilibrium depends upon the concentration on one side of a membrane of some ion to which it is impermeable, and no such ion is available in Beutner's systems.

It is with these systems, whose potential depends upon difference of salt concentration, that Beutner has been able to show the most striking analogies between 'oils' and the substances which he entitles 'physiological objects'. Uninjured apple-skin, for example, shows a concentration effect markedly similar to that of an 'oil' containing free acid. The parallelism of the two experiments is very striking, and the discovery may well be of value as a method of investigating differences in various kinds of cuticle, but it cannot take us very far in the interpretation of the cellular mechanism of the cell. Apple-skin, with its coating of wax and specialized nature, is very far removed from the plasma membrane of the living cell, and Beutner finds that tissues without cuticle do not give very definite

\footnotetext{
1 Journ. Gen. Physiol, iv. 35 I (I922).
} 
indications. It is hardly necessary to point out at the present time that no membrane which acts merely by restricting solubility can serve to explain the differences of permeability which the living cell exhibits. Such a membrane could not maintain differences of concentration ${ }^{1}$ on either side of it, and if it were permeable to a dilute solution, a concentrated solution would penetrate very rapidly. It is therefore no analogue of the plasma membrane, and Beutner's claim to have rendered a service to electrophysiology similar to that rendered by Nernst to electrochemistry would seem to be somewhat insecurely founded, even if the physical basis of his theory were satisfactory.

\section{The CURrent of Injury.}

Beutner concludes his work by an attempt to explain the 'current of injury' in apples. He regards this as a consequence of the system

\begin{tabular}{c|c|c|c}
$\begin{array}{c}\text { conducting } \\
\text { solution }\end{array}$ & $\begin{array}{c}\text { membrane containing } \\
\text { acid (cuticle) }\end{array}$ & $\begin{array}{c}\text { membrane containing } \\
\text { a small amount of } \\
\text { acid (flesh of fruit) }\end{array}$ & $\begin{array}{c}\text { conducting } \\
\text { solution }\end{array}$
\end{tabular}

and he compares this with Cremer's nitrobenzene system, which is positive on the acid side. Beutner states that the outer skin of an apple consists of a mixture of fatty acids and higher alcohols, and that the tissue itself contains far less acid, but he does not state whence his information is derived; and on the basis of experiments on uncut apples, in which he found that the expressed juice showed no difference of potential against $\mathrm{M} / 5 \circ \mathrm{KCl}$, he considers himself justified in regarding the hydrogen ion content of the juice as without electrochemical effect. This latter proposition can hardly be maintained. What Beutner really shows is that the sum of the potentials at $A, B$, and $C$ is zero in the system

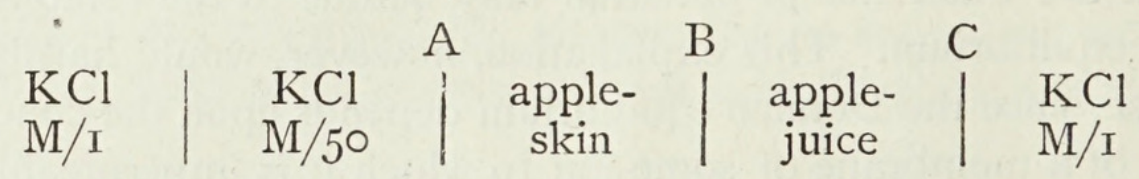

When the 'current of injury' is in question a different set of phase boundaries arises-among them the junction of the waxy layer with the cell-walls, which in the writer's opinion may play an important part, since the cell-wall is likely to contain free acid in aqueous solution. Further experiments are needed before the phenomenon of the 'current of injury' in apples can usefully be made the subject of detailed discussion; it is most certainly valueless to attempt to interpret it in terms of a system which postulates for the fruit a homogeneous 'flesh'. Beutner has rendered a real service to physiology by laying stress on the wide range of electrical phenomena which is shown by simple diphasic systems. It is unfortunate that the value of his work should be diminished by faulty interpretation and its significance minimized by an attempt to make it the basis of a general

\footnotetext{
${ }^{1}$ Cf. Osterhout : Journ. Gen. Physiol., v. 225, 1922
} 
explanation of bio-electrical phenomena. On the physical side he fails altogether to substantiate his statement that salts rather than acids play the predominating rôle in the systems he investigates. A careful review of the experimental evidence shows that the differences of potential which he obtains can be correlated with a difference of hydrogen ion concentration whenever free acid is present in the 'oil', and that the theory' of salt action is derived from a misinterpretation of the complex chemical systems with which he deals.

On the biological side Beutner lays himself open to serious criticism. He claims to have superseded such unproved theories as that of differential permeability by a theory resting on clearly ascertained facts; but on examination these 'facts' prove to be little more than a reintroduction of the lipoid theory without consideration of any of the difficulties which this theory has already encountered, and in his attempt to provide a solution for particular problems-in his theory of the current of injury and in the analogy which he appears to seek between cuticle such as apple-skin and the plasma membrane of the cell-Beutner assumes a simplicity and uniformity of structure for the living organism to which no physiologist can give countenance. 


\section{$2 \mathrm{BHL}$ Biodiversity Heritage Library}

Haynes, Dorothy. 1923. "A criticism of Beutner's theory of the electromotive force of diphasic liquid systems and their relation to bio-electrical phenomena." Annals of botany 37, 95-103. https://doi.org/10.1093/oxfordjournals.aob.a089839.

View This Item Online: https://www.biodiversitylibrary.org/item/270686

DOI: https://doi.org/10.1093/oxfordjournals.aob.a089839

Permalink: https://www.biodiversitylibrary.org/partpdf/319070

\section{Holding Institution}

New York Botanical Garden, LuEsther T. Mertz Library

\section{Sponsored by}

BHL-SIL-FEDLINK

\section{Copyright \& Reuse}

Copyright Status: Public domain. The BHL considers that this work is no longer under copyright protection.

This document was created from content at the Biodiversity Heritage Library, the world's largest open access digital library for biodiversity literature and archives. Visit BHL at https://www.biodiversitylibrary.org. 